\title{
PENERAPAN VIDEO PEMBELAJARAN MANDIRI BERBANTUAN SOFTWARE CAMSTUDIO DAN PEN TABLET PADA PERKULIAHAN ALJABAR LINIER
}

\author{
Ucu Koswara ${ }^{1}$, Neneng Tita Rosita ${ }^{2}$ \\ ${ }^{1,2}$ STKIP Sebelas April \\ ${ }^{1}$ ucu_koswara@stkip11april.ac.id \\ 2tita_rosita@stkip11april.ac.id
}

\begin{abstract}
ABSTRAK
Video pembelajaran matematika merupakan salah satu media pembelajaran berbasis audio visual yang saat ini belum banyak digunakan, dikarenakan disamping waktu pembuatannya yang cukup lama, juga memerlukan penguasaan khusus dalam bidang komputer dan software pembelajaran. Latar belakang dari penelitian ini difokuskan pada pentingnya penguatan kemampuan mahasiswa terhadap materi perkuliahan yang dilakukan secara mandiri setelah proses pembelajaran di kelas dilaksanakan. Penelitian ini bertujuan untuk mengkaji dan menganalisis perbedaan hasil belajar yang signifikan antara kelompok yang diberi perkuliahan dengan tambahan Video Pembelajaran Mandiri yang dibuat dengan Menggunakan Software Cam Studio dan Pen Tablet pada Perkuliahan Aljabar Linier dan kelompok yang diberi perkuliahan biasa. Metode penelitian ini menggunakan metode Pre-eksperimental design dengan Tipe One-Shot Case Study terhadap seluruh mahasiswa semester IV Jurusan Pendidikan Matematika STKIP Sebelas April Sumedang yang terdiri dari dua kelompok yang diambil secara purposive. Data hasil penelitian di analisis dengan uji beda dua rata-rata terhadap dua kelompok yang mendapat perlakuan berbeda. Hasil penelitian ini menunjukkan bahwa terdapat perbedaan hasil belajar yang signifikan antara kelompok yang diberi perkuliahan dengan tambahan Video Pembelajaran Mandiri yang dibuat dengan Menggunakan Software Cam Studio dan Pen Tablet pada Perkuliahan Aljabar Linier dan kelompok yang diberi perkuliahan biasa.
\end{abstract}

Kata Kunci: Aljabar linier, Video pembelajaran, Cam Studio, Hasil Belajar

\begin{abstract}
Video on learning of mathematics is one of the audio-visual media-based learning which is currently not widely used, because in addition need quite a long time, and also need requires special mastery in the field of computers and learning software. The background of this research focused on the importance of strengthening the ability of students to the course material which is conducted independently after the learning process in the classroom implemented. This study aims to examine and analyse the significant differences in learning outcomes between groups given lectures with the addition of Independent Learning Videos made using Cam Studio Software and Pen Tablets in Linear Algebra Lectures and groups that are given regular lectures. This research method using pre-experimental design with type One-Shot Case Study of the entire fourth semester students of the majoring in mathematics education in STKIP Sebelas April Sumedang that consisting of two groups taken purposively. The data was analysed by two different test average ( $t$ test) of the two groups that received different treatment. These results indicate that there are significant differences in learning outcomes between the groups were given a course with additional self-learning video by using Cam studio Software and Pen Tablet on Linear Algebra Class and the group given regular course.
\end{abstract}

Keywords: Linier algebra, learning video pembelajaran, Cam Studio, Learning outcomes. 


\section{PENDAHULUAN}

Proses pembelajaran matematika yang mengoptimalkan semua kemampuan siswa dalam proses pembelajaran menjadi perhatian dunia pendidikan saat ini (Yusepa, Kusumah, Kartasasmita; 2018). Begitupun pembelajaran yang melibatkan teknologi, sekarang ini menjadi perhatian di kalangan dunia pendidikan khususnya pada pembelajaran matematika. Guru memiliki peranan penting dalam proses pembelajaran dan dalam meningkatkan pendidikan nasional serta menjadi garda terdepan pendidikan (Yusepa, 2016).

Sifat keabstrakan matematika sebagai materi yang memerlukan tingkat berpikir logis dan rasional menuntut peran guru atau dosen untuk mempermudah dan menanamkan penguatan konsep sehingga mengoptimalkan proses dan hasil belajar siswa atau mahasiswa. Komputer sebagai media pembelajaran sudah menjadi alat bantu yang handal untuk menjembatani pengembangan kemampuan dan motivasi yang dimiliki mahasiswa terutama dalam pembelajaran matematika. Menurut Koswara, Yuliawati, dan Rosita, (2017), komputer yang dipadukan dengan program-program tertentu dapat dimanfaatkan oleh guru atau dosen sebagai media pembelajaran yang dapat mengeksplorasi dan mengkonstruksi konsep-konsep matematika seperti geometri, statistic, topologi, numerik, sehingga lebih akurat dan lebih kongkrit.

Dosen yang memiliki peran sektoral pada proses ini selayaknya mempersiapkan kemungkinan menghadapi tantangan dalam menguasai dan menerapkan teknologi pembelajaran yang berkembang untuk di integrasikan dalam proses perkuliahan serta meningkatkan karya inovatif dalam membuat media pembelajaran untuk perkuliahan. Berdasarkan hasil observasi peneliti terhadap mahasiswa terkait dengan proses belajar bahwa sebagian besar mahasiswa jarang membuka kembali catatan perkuliahan atau mempelajari kembali pokok bahasan yang diberikan oleh dosen pasca perkuliahan. Mahasiswa cenderung membaca dan mempelajari kembali pokok bahasan itu jika akan dilakukan evaluasi pada Ujian Tengah Semester (UTS) atau Ujian Akhir Semester (UAS) atau paling tidak jika diberikan tugas-tugas mandiri, itu pun hanya poin-poin tertentu melalui (handout) yang diberikan dosen setelah perkuliahan.

Dalam mengantisipasi masalah tersebut, dosen harus membuat langkah antisipatif dalam memperbaiki kualitas pembelajaran dengan berbagai cara tersendiri terutama penguatan belajar mahasiswa setelah proses perkuliahan dilakukan, dalam hal ini peneliti mencoba untuk merubah teknik pemberian materi dan tugas yang terintegrasi menjadi sebuah video pembelajaran yang 
diberikan kepada mahasiswa setelah selesai perkuliahan. Beberapa penelitian khusus telah menunjukkan bahwa video pembelajaran dapat menjadi alat pendidikan yang sangat efektif (Kay, 2012; Schmid et al, 2014; Moore \& Smith, 2012; Lloyd \& Robertson, 2012; Rackaway, 2012; Hsin \& Cigas, 2013). Komputer dengan desain software yang baik dapat mendukung perkembangan kemampuan mahasiswa dalam bereksplorasi terhadap materi matematika yang sedang dihadapinya. Karakteristik unik tersebut sangat jarang dijumpai dalam media pembelajaran lainnya. Peneliti mencoba membuat video ini sebagai alat bantu dalam memperkuat penguasaan konsep materi perkuliahan yang dapat dipelajari di rumah secara mandiri atau kelompok. Mahasiswa dapat mempelajari secara berulang-ulang materi yang dipelajari di media laptop, televisi, YouTube dengan santai dan menyenangkan.

\section{Media Pembelajaran}

Secara bahasa arti kata media berasal dari bahasa latin yaitu medius yang berarti 'tengah', 'perantara', atau 'pengantar' (Arsyad, 2011) dan pembelajaran menurut Kamus Besar Bahasa Indonesia berarti proses, cara, perbuatan yang menjadikan orang atau makhluk hidup belajar (KBBI, 2005). Berdasarkan apa yang dipaparkan di atas maka dapat dikatakan bahwa media pembelajaran merupakan media yang digunakan dalam proses pembelajaran yang berfungsi menyampaikan pesan atau informasi dari guru ke siswa atau dari dosen ke mahasiswanya agar tujuan dari pembelajaran itu dapat tercapai. Dalam proses belajar mengajar keberadaan media menjadi sangat penting, kemungkinan dari ketidakjelasan, kerumitan dari suatu materi yang disampaikan dapat dibantu dengan menghadirkan media sebagai perantara. Selain itu media juga dapat menjadi sarana yang dapat menutupi keterbatasan seorang pengajar dalam hal kata-kata atau kalimat, keabstrakan, perhitungan, ataupun visual grafis.

Menurut Leshin et al. (1992) dalam Arsyad (2011) menyatakan bahwa media pembelajaran dapat dikelompokkan sebagai berikut; 1) media berbasis manusia (guru/dosen, instruktur, tutor, main-peran, kegiatan kelompok, field-trip), 2) media berbasis cetak (buku, penuntun, buku latihan, alat bantu kerja, dan lembaran lepas), 3) media berbasis visual (buku, chart, grafik, peta, gambar, transparansi, slide), 4) media berbasis audio-visual (video, film, program slide tape, televisi). 5) media berbasis komputer (pengajaran dengan berbantuan komputer, video interaktif, hypertext).

Dari kelima kelompok media pembelajaran tersebut yang saat ini menjadi pembicaraan dan banyak dilakukan seminar-seminar tentang media pembelajaran adalah kelompok media 
pembelajaran berbasis audio-visual dan media berbasis komputer. Hal tersebut dikarenakan tuntutan penguasaan teknologi sekarang ini menjadi sangat penting dikuasai oleh para pengajar dalam hal ini para dosen sehingga dapat menyeimbangkan penguasaan teknologi informasi dan komputer untuk membuat suatu pembelajaran menjadi menarik dan efektif bahkan bisa menjadi pemicu peserta didik menjadi lebih kreatif.

Menurut (Arsyad, 2011) secara umum media pembelajaran memiliki manfaat sebagai berikut, 1) Media pembelajaran dapat memperjelas penyajian pesan dan informasi sehingga dapat memperlancar dan meningkatkan proses serta hasil belajar, 2) media pembelajaran dapat meningkatkan dan mengarahkan perhatian anak sehingga dapat menimbulkan motivasi belajar, interaksi yang lebih langsung antara siswa dan lingkungannya, dan kemungkinan siswa untuk belajar sendiri-sendiri sesuai dengan kemampuan dan minatnya, 3) media pembelajaran dapat mengatasi keterbatasan indera, ruang, dan waktu, 4) media pembelajaran dapat memberikan kesamaan pengalaman kepada siswa tentang peristiwa-peristiwa di lingkungan mereka, serta memungkinkan terjadinya interaksi langsung.

Sesuai dengan apa yang dipaparkan di atas maka jelaslah bahwa media pembelajaran menjadi suatu hal yang sangat diperlukan seorang pengajar untuk menghilangkan kesenjangan atau mengoptimalkan penyampaian informasi atau ilmu pengetahuan dari pengajar ke pembelajar.

\section{Video Pembelajaran Matematika}

Menurut Hanson (1987) video adalah bentuk unik dari komunikasi visual yang berhubungan dengan proses yang dapat menunjukkan suatu citra visual yang sebenarnya. Secara bahasa, video sebenarnya berasal dari bahasa Latin, video-vidi-visum yang artinya melihat (mempunyai daya penglihatan); dapat melihat (K. Prent dkk., Kamus Latin-Indonesia, (1969) Sedangkan dalam Kamus Besar Bahasa Indonesia (1995) mengartikan video dengan: 1) bagian yang memancarkan gambar pada pesawat televisi; 2) rekaman gambar hidup untuk ditayangkan pada pesawat televisi.

Dari beberapa definisi di atas, dapat disimpulkan bahwa video itu sangat berhubungan dengan sesuatu yang dapat dilihat, suatu gambar yang dapat bergerak, memerlukan suatu proses perekaman, dan penayangannya yang tentunya melibatkan teknologi. Dalam hal ini media pembelajaran matematika berarti suatu tampilan pembelajaran menggunakan video yang di dalamnya mencakup proses untuk mempelajari materi matematika. 
Menurut Riyana (2007) media video pembelajaran adalah media yang menyajikan audio dan visual yang berisi pesan-pesan pembelajaran baik yang berisi konsep, prinsip, prosedur, teori aplikasi untuk membantu pemahaman terhadap suatu materi pembelajaran. Media audio visual dapat dibagi menjadi dua jenis: pertama, dilengkapi fungsi peralatan suara dan gambar dalam satu unit, dinamakan media audio-visual murni; dan kedua, media audio-visual tidak murni. Film bergerak (movie), televisi, dan video termasuk jenis yang pertama, sedangkan slide, opaque, OHP dan peralatan visual lainnya yang diberi suara termasuk jenis yang kedua.

Menurut Smaldino dkk (2008), terdapat kelebihan dan kekurangan dalam menggunakan video untuk pembelajaran diantaranya adalah video pembelajaran merupakan media yang sangat cocok untuk cakupan banyaknya siswa dalam pembelajaran, seperti kelas, kelompok kecil, bahkan satu siswa seorang diri sekalipun. Dengan menggunakan video pembelajaran maka sangat dimungkinkan untuk pembelajar dapat belajar secara mandiri. Selain itu, video pembelajaran juga bisa dimanfaatkan untuk hampir semua topik, tidak hanya dalam pembelajaran matematika saja, tipe belajar dan setiap ranah: kognitif, afektif, psikomotor, dan interpersonal.

Pada ranah kognitif, pembelajar bisa mengobservasi struktur, pola, analisis, grafik, dan lain sebagainya dalam matematika karena unsur warna, suara dan gerak di sini mampu membuat karakter berasa lebih hidup. Selain itu menonton video, setelah atau sebelum membaca, dapat memperkuat pemahaman mahasiswa terhadap materi ajar. Menurut Rifa'i (2015) aspek kognitif merupakan tujuan pendidikan yang berkesinambungan dengan ingatan terhadap pengetahuan, pengembangan kemampuan dan kemahiran intelektual.

Pada ranah afektif, video dapat memperkuat siswa dalam merasakan unsur emosi dan penyikapan dari pembelajaran yang efektif. Hal ini tidak dapat dilepaskan dari potensi emosional impact yang dimiliki oleh video, di mana ia mampu secara langsung menggiring pada sisi penyikapan personal dan sosial siswa. Membuat mereka gembira, atau sebaliknya menjadi bingung atau penasaran terhadap fakta atau konsep dalam matematika. Dan lebih dari itu, menggiring mereka pada penyikapan seperti menolak argument, atau sebaliknya pemihakan kepada fakta atau konsep dalam matematika itu sendiri. Menurut Rifa'i (2015: 69) meliputi tujuan pendidikan yang berkenaan dengan sikap, minat, dan nilai.

Pada ranah psikomotor, video memiliki keunggulan dalam memperlihatkan bagaimana sesuatu bekerja. Misalnya dalam mendemonstrasikan bagaimana mengukur panjang, 
menghitung luas suatu daerah, atau pemakaian algoritma tertentu. Semua itu akan terasa lebih simpel, mendetail, dan bisa diulang-ulang. Video pembelajaran yang merekam kegiatan motorik siswa juga memberikan kesempatan pada mereka untuk mengamati dan mengevaluasi kerja mereka, baik secara pribadi maupun feedback dari teman-temannya.

Sedangkan pada ranah meningkatkan kompetensi interpersonal, video memberikan kesempatan pada mereka untuk mendiskusikan apa yang telah mereka saksikan secara bersamasama. Misalnya tentang penjelasan suatu aksioma dan teorema, mereka bisa saling mengobservasi dan menganalisis sebelum menyaksikan tayangan video.

Lebih dari itu, manfaat dan karakteristik lain dari media video pembelajaran dalam meningkatkan efektifitas dan efisiensi proses pembelajaran, di antaranya; 1) dapat mengatasi jarak dan waktu; 2) dapat membawa peserta didik bertualang dari negara satu ke negara lainnya, dan dari masa yang satu ke masa yang lain; 3) dapat diulang-ulang bila perlu untuk menambah kejelasan; 4) pesan yang disampaikannya cepat dan mudah diingat; 4) mengembangkan pikiran dan pendapat para peserta didik; 5) dapat mengembangkan imajinasi; 6) dapat memperjelas halhal yang abstrak dan memberikan penjelasan yang lebih realistik; 7) mampu berperan sebagai storyteller yang dapat memancing kreativitas peserta didik dalam mengekspresikan gagasannya (Smaldino, 2011).

Selain kelebihan, video/film juga memiliki kekurangan, di antaranya: sebagaimana media audio-visual yang lain, video juga terlalu menekankan pentingnya materi daripada proses dari pengembangan materi tersebut serta memerlukan waktu yang cukup lama hanya untuk membuat satu video pembelajaran saja; pemanfaatan media ini juga terkesan memakan biaya tidak murah, dan penayangannya juga terkait peralatan lainnya seperti video player, layar bagi kelas besar beserta LCD nya, dan lain-lain.

\section{Software Cam Studio dan Pen Tablet}

Cam Studio (gambar 1) adalah software video tutorial yang disediakan oleh camstudio.org secara gratis. Software ini sangat membantu dalam membuat video tutorial pembelajaran matematika karena dapat merekam segala aktivitas di layar monitor (screencast) beserta audio nya sehingga para pembelajar yang menyaksikan atau mempelajari pembelajaran tersebut dapat dengan mudah mengikuti langkah demi langkah yang kita lakukan. Hasil rekaman yang dibuat oleh software ini kemudian disimpan dalam format AVI atau MP4. Kualitas hasil rekaman Cam Studio cukup baik, sehingga software ini cocok untuk digunakan dalam 
pembuatan video tutorial atau video pembelajaran. Selain itu, Cam Studio memiliki fitur tambahan yang dapat digunakan untuk mengkonversi file berformat AVI hasil rekamannya ke format Streaming Flash videos (SWFs). Software Cam Studio ini sangat mudah untuk digunakan, dan fiturnya cukup lengkap.

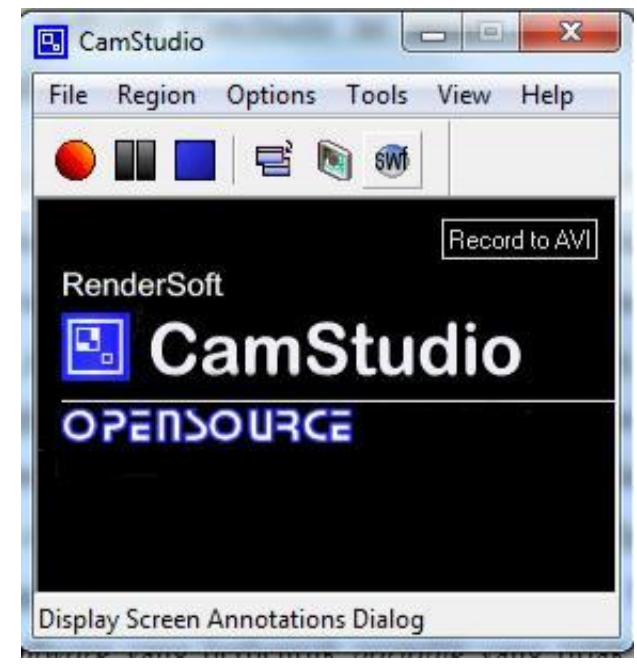

Gambar 1. Tampilan Awal Cam Studio

Video pembelajaran hasil perekaman dengan Cam Studio ini dapat dimainkan oleh beberapa video player misalnya GOM Player, Window Media Player, FLV Player dan lain-lain. Untuk memudahkan transfer kepada para mahasiswa, video pembelajaran ini dapat disebarluaskan dengan cara disalin melalui media flash disk atau CD atau diunggah melalui internet ke situs pribadi seperti BlogSpot atau situs video yang umum misalnya YouTube (youtube.com).

Pen Tablet (gambar 2) atau dapat pula dikatakan Tablet Grafis adalah perangkat keras (hardware) piranti masukan komputer yang membolehkan pemakainya untuk menggambar dengan tangan dan memasukkan gambar atau sketsa langsung ke komputer, layaknya menggambar di atas kertas menggunakan pensil (http://id.wikipedia.org/wiki/Tablet_grafis). 


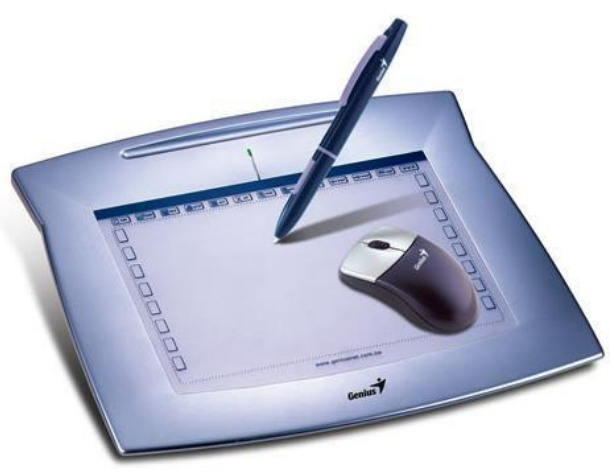

Gambar 2. Pen Tablet / Genius Tablet Mouse Pen $8 \times 6$

Sebuah tablet grafis terdiri dari tablet digital dan sebuah kursor ataupun sebuah pena digital (pen). Tablet digital memiliki permukaan yang pipih sebagai alas gambar yang terdiri atas perlengkapan elektronik yang dapat mendeteksi gerakan kursor atau pena digital kemudian menerjemahkannya menjadi sinyal digital yang dikirim langsung ke komputer. Setiap titik atau gerakan pada tablet merepresentasikan titik atau gerakan pada layer monitor, inilah yang membedakannya dengan fungsi mouse yang tergantung pada letak kursor. Hasil gambar tidak akan terlihat pada tablet itu sendiri, melainkan pada monitor komputer.

Dari apa yang dipaparkan di atas dapat dibuat video pembelajaran matematika (gambar 3) untuk dapat disebarkan kepada pembelajar dalam hal ini mahasiswa untuk memperkuat kemampuannya dalam mempelajari matematika secara mandiri.

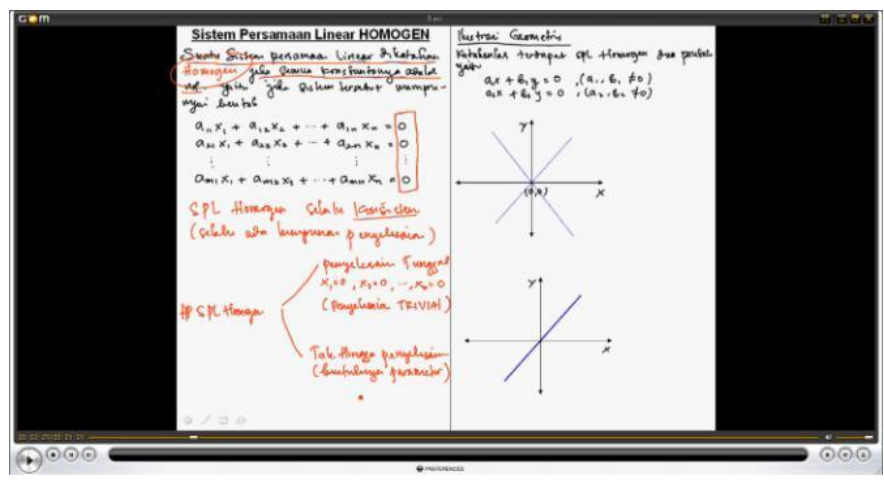

Gambar 3. Contoh Hasil Video Pembelajaran

\section{Pembelajaran Mandiri}

Pembelajaran mandiri merupakan bagian dari teori pembelajaran kognitif yang menyatakan bahwa perilaku, motivasi dan aspek lingkungan belajar akan mempengaruhi 
prestasi seorang pembelajar (Bell dan Akroyd, 2006). Perilaku dan motivasi individu sangat menentukan terhadap terjadi atau tidaknya proses belajar ini, dorongan dan kemauan untuk menguasai suatu pengetahuan timbul akibat dari adanya keingintahuan individu menjadi syarat timbulnya proses belajar mandiri. Proses pembelajaran ini dapat dikontrol secara langsung oleh individu atau kelompok secara otonom dengan materi atau pengetahuan sesuai dengan konteks yang diberikan. Hal ini sejalan dengan apa yang dikatakan oleh Chamot (1999) menyatakan bahwa, pembelajaran mandiri adalah sebuah situasi belajar di mana pembelajar memiliki kontrol terhadap proses pembelajaran tersebut melalui pengetahuan dan penerapan strategi yang sesuai, pemahaman terhadap tugas-tugasnya, penguatan dalam pengambilan keputusan dan motivasi belajar. Lebih lanjut Yusepa (2016), Widiawati dan Koswara (2016), Rosita dan Jenudin (2017), dan Yusepa, Kusumah, dan Kartasasmita (2018), membangun konsep matematis secara mandiri oleh siswa merupakan hal yang mendasar dalam pembelajaran matematika. Kegiatan pembelajaran mandiri sangat mendukung terhadap karakteristik mahasiswa yang dituntut untuk memiliki sikap kemandirian dan segala hal terutama menyangkut pemahaman mereka akan ilmu pengetahuan. Keterbatasan tatap muka pada proses perkuliahan menjadikan mahasiswa harus dapat mencari dan mendalami pengetahuannya secara mandiri atau berkelompok guna memperluas wawasan ilmu pengetahuan. Mahasiswa dituntut secara proaktif untuk mencari sumber-sumber yang lebih luas untuk memperkuat pengetahuan yang diajarkan, sumber-sumber tersebut dapat berupa buku, jurnal, internet, hand out dan video pembelajaran yang disediakan dosen untuk dipelajari secara mandiri oleh mahasiswa. Kegiatan belajar mandiri selain dapat meningkatkan pengetahuan yang lebih luas juga dapat meningkatkan kepekaan diri terhadap situasi belajar yang dihadapi sehingga mahasiswa dapat lebih kritis terhadap pengetahuan yang diajarkan. Hal ini sesuai dengan pendapat Montalvo dan Torres (2004) berpendapat bahwa, mahasiswa yang telah mampu melakukan pembelajaran mandiri akan tercermin dari kemampuan mereka berpartisipasi aktif dalam pembelajaran baik dari segi meta kognitif, motivasi dan kesungguhan perilaku dalam pencapaian tujuan belajar.

Dalam penelitian ini, pembelajaran mandiri tidak diartikan sebagai model pembelajaran, akan tetapi konteksnya diperluas dengan mengaitkannya pada video pembelajaran, artinya suatu kegiatan mahasiswa yang melakukan proses belajar baik secara individu atau kelompok di luar proses perkuliahan dengan menggunakan media video. Mahasiswa setelah proses perkuliahan selesai diberikan pendalaman materi bukan dalam bentuk hand out melainkan dengan media 
video pembelajaran yang dibuat dosen dengan menggunakan software Cam Studio dan Pen Tablet dengan materi Aljabar Linier untuk dipelajari lebih lanjut baik secara individu atau kelompok mahasiswa secara mandiri.

\section{METODE PENELITIAN}

Metode penelitian ini menggunakan metode Pre-eksperimental design dengan Tipe OneShot Case Study terhadap seluruh mahasiswa semester IV Jurusan Pendidikan Matematika STKIP Sebelas April Sumedang yang terdiri dari dua kelompok yang diambil secara purposive. Kegiatan penelitian ini mengambil materi yang diampu oleh peneliti yaitu materi kuliah Aljabar Linier (3 SKS) selama 12 minggu, di dalamnya termasuk tahap persiapan, pelaksanaan, analisis dan penyusunan makalah penelitian. Instrument dalam penelitian ini berupa tes uraian pada materi kuliah Aljabar Linier sebanyak 7 butir soal. Analisis data dilakukan dengan mengikuti prosedur statistika parametrik yaitu menggunakan uji perbedaan dua rata-rata (uji $t$ ) terhadap dua kelompok. Pada tahap persiapan dilakukan selama 3 minggu.

Kegiatan ini menitikberatkan pada studi pendahuluan dan pembuatan model video pembelajaran dengan menggunakan Software Cam Studio dan Pen tablet pada materi Aljabar Linier sebanyak enam buah video untuk enam kali pertemuan efektif. Pada tahap pelaksanaan dilakukan proses pembelajaran pada dua kelompok kelas. Untuk kelompok pertama setelah proses perkuliahan selesai setiap mahasiswa diberikan video pembelajaran yang telah dibuat, di dalamnya sudah termasuk pendalaman materi dan tugas dan untuk kelompok yang kedua setelah proses pembelajaran hanya diberikan hand out dan tugas tertulis. Pada tahap analisis, hasil tes setelah enam kali proses perkuliahan dianalisis secara statistik untuk melihat perbedaan hasil belajar antara kedua kelompok tersebut.

\section{HASIL DAN PEMBAHASAN}

Data kuantitatif yang diperoleh dari hasil penelitian ini didapat melalui ujian tertulis (pencil and paper test) yang dilakukan pada kedua kelompok di akhir pertemuan (posttest).

Tabel 1. Statistik Deskriptif Skor Postest Mahasiswa Kelas Eksperimen dan Kelas Kontrol

\begin{tabular}{cccccc}
\hline \multirow{2}{*}{ Kelas } & \multicolumn{5}{c}{ Hasil Tes } \\
\cline { 2 - 6 } & $n$ & $x_{\min }$ & $x_{\text {maks }}$ & $\bar{x}$ & $S$ \\
\hline Eksperimen & 31 & 44 & 80 & 59,84 & 9,13 \\
Kontrol & 31 & 26 & 70 & 47,10 & 11,98 \\
\hline
\end{tabular}


Secara umum hasil dari analisis data menggambarkan keadaan rata-rata dari dua kelompok terlihat berbeda yaitu untuk kelas eksperimen didapat rata-rata sebesar 59.84 dengan deviasi standar 9.13, sedangkan untuk kelas kontrol didapat 47.10 dengan deviasi standar 11.98. keadaan ini dapat diartikan bahwa tingkat penguasaan hasil belajar setelah dilakukan tes untuk kelas eksperimen cenderung heterogen di setiap mahasiswanya. Perbedaan rata-rata hanya terpaut 12.74 lebih tinggi dari kelas kontrol, artinya bahwa terdapat perbedaan hasil belajar yang signifikan antara kelas eksperimen dengan kelas kontrol. Namun untuk melihat signifikansi atau ada tidaknya perbedaan tersebut maka harus dilakukan uji statistic parametrik, dengan terlebih dahulu menguji normalitas dan uji kesamaan dua rata-rata. Adapun hasil uji normalitas disajikan pada Tabel 2.

Tabel 2. Uji Normalitas

\begin{tabular}{ccccccc}
\hline Kelas & $N$ & $\bar{x}$ & $S$ & $X^{2}$ hitung & $X^{2}$ tabel & $\begin{array}{c}\text { Kriteria } \\
\text { Pengujian }\end{array}$ \\
\hline Eksperimen & 31 & 59,84 & 9,13 & 8,37 & 11,3 & $\mathrm{H}_{0}$ diterima \\
Kontrol & 31 & 47,10 & 11,98 & 5,07 & 11,3 & $\mathrm{H}_{0}$ diterima \\
\hline
\end{tabular}

Pada Tabel 2 di atas terlihat bahwa $X^{2}$ hitung pada taraf signifikansi $1 \%$ pada kelas eksperimen dan kelas kontrol lebih kecil dari $X^{2}$ tabel. Artinya bahwa kelas eksperimen dan kelas kontrol berasal dari populasi yang berdistribusi normal, maka perhitungan dilanjutkan dengan uji homogenitas dua varian. Adapun perhitungan dengan uji homogenitas dua varian sebagai berikut.

Tabel 3. Uji Homogenitas

\begin{tabular}{ccccc}
\hline Kelas & Varian $\left(S^{2}\right)$ & $\mathrm{F}_{\text {hitung }}$ & $\mathrm{F}_{\text {tabel }}$ & Keterangan \\
\hline Eksperimen & 84,41 & \multirow{2}{*}{0,581} & 2,34 & $\mathrm{H}_{0}$ diterima \\
Kontrol & 143,62 & & & \\
\hline
\end{tabular}

Pada Tabel 3 di atas terlihat bahwa pada taraf signifikansi $1 \%$, nilai $F_{\text {hitung }}=0,581$ dan $F_{\text {tabel }}=2$,386. Artinya $\mathrm{F}_{\text {hitung }} \leq \mathrm{F}_{\text {tabel }}$ sehingga $\mathrm{H}_{0}$ diterima maka kedua varians homogen. Setelah diketahui kedua sampel berdistribusi normal dan variansnya homogen maka dilanjutkan dengan uji kesamaan dua rata-rata menggunaan uji t. Berdasarkan perhitungan dengan menggunaan uji t diperoleh $t_{\text {hitung }}$ dan $t_{\text {tabel }}$ dari kelas eksperimen dan kelas kontrol sebagai berikut. 
Tabel 4. Tabel Uji Perbedaan Dua Rata-Rata Kelas Eksperimen dan Kelas Kontrol

\begin{tabular}{ccccccc}
\hline Kelas & $n$ & $\bar{x}$ & $s$ & $t_{\text {hitung }}$ & $t_{\text {tabel }}$ & keterangan \\
\hline Eksperimen & 31 & 59,84 & 9,13 & \multirow{2}{*}{4,71} & 2,65 & \multirow{2}{*}{$\mathrm{H}_{0}$ ditolak } \\
Kontrol & 31 & 47,10 & 11,98 & & & \\
\hline
\end{tabular}

Dari Tabel 4 di atas, dapat dilihat bahwa nilai $t_{\text {hitung }}$ sebesar 4,71 sedangkan nilai $t_{\text {tabel }}$ pada taraf signifikansi $1 \%$ dan $\mathrm{dk}=60$ adalah sebesar 2,65. Karena nilai $t_{\text {hitung }}$ berada diluar interval $-t_{\text {tabel }}=-2,65$ dan $t_{\text {tabel }}=2,65$ maka $\mathrm{H}_{\mathrm{a}}$ diterima. Artinya terdapat perbedaan hasil belajar yang signifikan antara kelompok yang diberi perkuliahan dengan tambahan Video Pembelajaran Mandiri yang dibuat dengan Menggunakan Software Cam Studio dan Pen Tablet pada Perkuliahan Aljabar Linier dan kelompok yang diberi perkuliahan biasa.

Hal ini membuktikan bahwa terdapat perbedaan hasil belajar yang signifikan antara kelompok yang diberi perkuliahan dengan tambahan Video Pembelajaran Mandiri yang dibuat dengan Menggunakan Software Cam Studio dan Pen Tablet pada Perkuliahan Aljabar Linier dan kelompok yang diberi perkuliahan biasa. Hasil dari proses analisis ini memperkuat dugaan bahwa video pembelajaran yang diberikan dapat membuat mahasiswa lebih menguasai materi perkuliahan yang dilakukan secara mandiri daripada hanya dengan memberikan materi melalui paper/handout.

\section{KESIMPULAN}

Berdasarkan hasil analisis data yang telah lakukan dapat disimpulkan bahwa terdapat perbedaan hasil belajar yang signifikan antara kelompok yang diberi perkuliahan dengan tambahan Video Pembelajaran Mandiri yang dibuat dengan Menggunakan Software Cam Studio dan Pen Tablet pada Perkuliahan Aljabar Linier dan kelompok yang diberi perkuliahan biasa.

Hasil penelitian ini diharapkan dapat diaplikasikan oleh guru atau dosen sebagai pendidik dikarenakan video pembelajaran yang diberikan dapat membuat mahasiswa lebih menguasai materi perkuliahan yang dipelajari secara mandiri daripada hanya dengan memberikan materi melalui paper/handout. Hasil pembuatan video juga dapat di share secara lebih luas untuk memperkaya khasanah ilmu pengetahuan. Sejalan dengan perkembangan teknologi yang semakin pesat, sebuah video pembelajaran dapat dimainkan di berbagai media seperti laptop/komputer, televisi yang memiliki fasilitas USB dan dapat ditransfer/diunggah ke situs video seperti YouTube oleh dosen yang bersangkutan. Selain itu, dapat membelajarkan 
mahasiswa tentang pentingnya teknologi dalam pembelajaran untuk diaplikasikan pada suatu saat mereka menjadi guru di sekolah.

\section{REKOMENDASI}

Arsyad A., (2011)., Media Pembelajaran. Jakarta: PT Rajagrafindo Persada.

Bell, P.D. dan Akroyd, D., (2006)., Can Factors Related to Self-Regulated Learning Predict Learning Achievement in Undergraduate Asynchronous Web based Course? International Journal of Instructional Education and Distance Learning. ISSN: 1550-6908.

Chamot, A.U., Barnhardt, S, E Dinary P. B. \& Robbins, J., (2000)., The Learning Strategies Handbook. New York: Addison-Wesley

Hanson, J., (1987)., Understanding Video Applications, Impact, and theory. California: SAGE Publications, Inc.

Hsin, W.J. \& Cigas J. (2013). Short videos improve student learning in online education. Journal of Computing Sciences in Colleges, 28, 253-259.

Kay, R.H. 2012. Exploring the use of video podcasts in education: A comprehensive review of the literature. Computers in Human Behaviour 28, 820-831.

Koswara, U., Yuliawati, T, dan Rosita, N.T. (2017). Pelatihan Program GeoGebra Bagi Guru Matematika SMP Di Kabupaten Sumedang. E-Dimas: Jurnal Pengabdian kepada Masyarakat, 8(1), 77-86.

Lloyd, S.A. \& Robertson, C.L. (2012). Screencast tutorials enhance student learning of statistics. Teaching of Psychology, 39(1) 67-71. https://doi.org/10.1177/ 0098628311430640.

Montalvo, F.T. and Torres, M.C.G. (2004)., Self-regulated Learning: Current and Future Direction. Electronic Journal of Research in Educational Psychology, 2(1), 1-34. ISSN:1696-2095.

Moore, W.A. \& Smith, A.R. (2012). Effects of video podcasting on psychomotor and cognitive performance, attitudes and study behaviour of student physical therapists. Innovations in Education and Teaching International 49, 401-414.

Rackaway, C. (2012). Video killed the textbook star? Use of multimedia supplements to enhance student learning. Journal of Political Science Education 8, 189-200.

Riyana, C., (2007).,. Pedoman Pengembangan Media Video. Jakarta: P3AI UPI.

Rifa'i A. RC \& C.T. Anni. 2015. Psikologi Pendidikan. Semarang: UNNES Press. 
Rosita, N. T., dan Jaenudin, A. (2017). Implementasi Pembelajaran Matematika dengan Pendekatan Open Ended terhadap Sikap Siswa. Symmetry: Pasundan Journal of Research in Mathematics Learning and Education, 1(1), 1-12.

Schmid, R.F., Bernard, R.M., Borokhovski, E., Tamim, R.M., Abrami, P.C., Surkes, M.A., Wade, C.A., \& Woods, J. (2014). The effects of technology use in postsecondary education: A meta-analysis of classroom applications. Computers \& Education, 72(c) 271-291.

Smaldino, S. E. dkk., (2011)., Instructional Technology \& Media for Learning Teknologi Pembelajaran dan Media untuk Belajar (Terjemahan. Edisi Kesembilan). Jakarta: Kencana Prenada Media Group.

Widiawati, A. S., dan Koswara, U. (2016). Implementasi Model Pembelajaran Resource Based Learning Berbantuan Program GeoGebra Dalam Upaya Meningkatkan Kemampuan Pemahaman Konsep Matematis. Symmetry: Pasundan Journal of Research in Mathematics Learning and Education, 1(1), 67-78.

Yusepa, B. (2016). Kemampuan abstraksi matematis siswa Sekolah Menengah Pertama (SMP) KLS VIII. Symmetry: Pasundan Journal of Research in Mathematics Learning and Education, 01(01), 54-60.

Yusepa, B.G.P. (2016). Analisis Perbandingan Kurikulum Pendidikan Indonesia dan Inggris untuk Meningkatkan Kompetensi Pedagogik dan Kompetensi Profesional Guru Matematika. Prosiding Seminar Nasional Matematika dan Pendidikan Matematika: Strategi Mengembangkan Kualitas Pembelajaran Matematika Berbasis Riset. Unswagati. Hal. 346- 364. ISBN: 978-602-71252-1-6.

Yusepa, B. G. P., Kusumah, Y. S., and Kartasasmita, B. G. (2018). The enhancement of students' mathematical representation in junior high school using cognitive apprenticeship instruction (CAI). J. Phys.: Conf. Ser. 983012100.

Yusepa, B. G. P., Kusumah, Y. S., and Kartasasmita, B. G. (2018). Promoting middle school students' abstract thinking ability through cognitive apprenticeship instruction in mathematics learning. J. Phys.: Conf. Ser. 948012051. 